GRADIATION\&APPLICATIONS

ISSN 2466-4294 (online) | rad-journal.org

Vol. 3 | Issue 3 | pp. 159-164, 2018

doi: 10.21175/RadJ.2018.03.027

Original research paper

\title{
SAFETY CULTURE AS A KEY ISSUE OF RADIATION SAFETY IN MEDICAL ACTIVITIES WITH IONIZING RADIATION SOURCES*
}

\author{
Liudmyla Aslamova, Ielyzaveta Kulich ${ }^{\text {1** }}$, Oleg Nasvit², Nadiia Melenevska1 \\ ${ }^{1}$ Training and Research Center for Radiation Safety of Taras Shevchenko National University of Kyiv, Kyiv, Ukraine \\ ${ }^{2}$ State Agency of Ukraine on Exclusion Zone Management, Kyiv, Ukraine
}

\begin{abstract}
The term 'Safety Culture' was first defined in 1986. Nowadays it is introduced into all areas of activities with ionizing radiation sources. The importance of Safety Culture for medical applications mirrors rapid penetration of cutting-edge technologies in the field of medical equipment, hence the need to involve extremely competent personnel. Medical physicist and doctor bear joint responsibility for the quality of healthcare services. In Ukraine, it is increasingly recognized that national education system combined with formal certification schemes for the recognition of the expertise and competence play an important role to ensure the professionalism of individual practitioners in medical physics. National regulatory framework needs to be amended and updated to ensure an effective introduction of 'Safety Culture' into professional and regulation practice.
\end{abstract}

Key words: Medical activities, safety culture

\section{INTRODUCTION}

Since the 1980s, the International Atomic Energy Agency (IAEA) has been devoting considerable attention to safety culture issues due to the analysis and systematization of conclusions following the Chernobyl accident. The IAEA established a new conceptual approach to the definition of safety on nuclear power plants (NPP) as a concept that includes universal human and professional culture elements. The notions of occupational safety and safety psychology at the NPPs have been replaced by the safety culture notion that became one of the fundamental principles of protection in nuclear field nowadays. Thus, among international organizations, the IAEA to some extent took the lead as regards the solution of specific practical nuclear protection tasks. [1].

Ukraine is a member of the IAEA. Integration into the European Union is a national policy. Ukraine selected one of ten principles of "Further generations protection", namely not to accumulate radioactive waste. On the one hand, the equipment with radionuclides should be replaced with generating ionizing radiation sources equipment. On the other hand, radiation protection and safety procedures, as well as safety culture, should be effectively introduced during the use of cutting-edge technologies in medical activities with ionizing radiation sources. Therefore, this defines generally accepted official practice in many fields of professional and legal activity. In particular, international documents are actively implemented; international standards are implemented in the national law. However, national practice based on an outdated regulatory framework results in legal discrepancies. As a result, in Ukraine, all regular national procedures and processes, such as education, professional activities, regulation etc., operate in a framework that does not always comply with the international standards, including safety culture issues standards.

This article attempts to analyse Ukrainian nuclear energy use legislation in terms of safety culture issues and to compare it with the international documents. Also the description of medical physicists' education and training is presented, as persons who play a primary role in quality assurance and quality control of procedure, radiation protection and safety of personnel, patients and environment in medical activities related to nuclear energy use.

\section{MATERIALS AND METHODS}

Ukrainian regulatory framework was analysed in terms of safety culture in certain activities related to nuclear energy use. The findings were compared with the international recommendations and guidelines of the IAEA and the International Radiation Protection Association (IRPA) with regard to the implementation of safety culture principles in national practices.

\footnotetext{
* This paper was presented at the Sixth International Conference on Radiation and Applications in Various Fields of Research (RAD 2018), Ohrid, Macedonia, 2018.

kulichliza@gmail.com
} 
National classification of occupations and the curricula of Ukrainian higher education institutions were examined to analyse the state of play as regards professional training of medical physicists.

\section{THE ANALYSIS OF REGULATORY FRAMEWORK ON SAFETY CULTURE IN UKRAINE}

Both the IAEA [2] and European [3] Basic Safety Standards place great emphasis on the appointment of a professional-level person having the knowledge, skills and competences through training and experience needed to give radiation protection advice in order to ensure the effective protection of individuals, and whose competence in this respect is recognized by the competent authority. Under the IAEA BSS this role is termed a Qualified Expert (QE), and the EU BSS uses the term Radiation Protection Expert (RPE). The role of this person is to give authoritative advice to employers on matters relating to compliance with applicable legal requirements, in respect of occupational and public exposure.

This role has been recognised for many years within the profession as a key role for ensuring radiation safety. In 2008 the IRPA proposed to the International Labour Organisation (ILO) that the role of radiation protection expert be formally registered under the ILO system for the International Standard Classification of Occupations (ISCO). This was agreed, with the radiation protection expert being registered within the group of environmental and occupational health and hygiene professionals [4].

Ukrainian national classification of occupations features 'medical physicists', but their role and responsibilities are not described properly. Yet, this occupation is not included in the list of compulsory staff members for healthcare institutions that perform activities with nuclear energy use. In practice, engineers and radiologists are carrying out their role and perform duties of radiation protection officer.

The general IAEA document on radiation safety is called "Radiation Protection and Safety of Radiation Sources: International Basic Safety Standards. General Safety Requirements" BSS [2]. The key quotation from this document about the basics of safety culture is as follows:

"2.51. The principal parties shall promote and maintain safety culture by:

(a) Promoting individual and collective commitment to protection and safety at all levels of the organization;

(b) Ensuring a common understanding of the key aspects of safety culture within the organization;

(c) Providing the means by which the organization supports individuals and teams in carrying out their tasks safely and successfully, with account taken of the interactions between individuals, technology and the organization;

(d) Encouraging the participation of workers and their representatives and other relevant persons in the development and implementation of policies, rules and procedures dealing with protection and safety; (e) Ensuring accountability of the organization and of individuals at all levels for protection and safety;

(f) Encouraging open communication with regard to protection and safety within the organization and with relevant parties, as appropriate;

(g) Encouraging a questioning and learning attitude, and discouraging complacency, with regard to protection and safety;

(h) Providing means by which the organization continually seeks to develop and strengthen its safety culture."

It is known that term "safety culture" was introduced after the accident on Chernobyl Power Plant (ChPP) and defined in the report by the International Nuclear Safety Advisory Group "Safety culture, Safety series No.75-INSAG-4" [5]. Then it was actively implemented into different recommendations, guidelines, like [2] etc. Here are a few examples of safety culture definitions:

1. Safety culture is that assembly of characteristics and attitudes in organizations and individuals which established that, as an overriding priority, nuclear plant safety issues receive the attention warranted by their significance [5].

2. The assembly of characteristics and attitudes in organizations and individuals which establishes that, as an overriding priority, protection and safety issues receive the attention warranted by their significance [2], [3], [6]. This is nowadays definition.

It can be seen that the definitions are nearly the same, but the latter is amended, so as to be implemented in all fields of activities with nuclear energy and radiation sources.

Poor regulatory framework in Ukraine is the general problem to implement safety culture principles for certain activities related to nuclear energy use in medicine. On the one hand, a statement "for certain activities related to nuclear energy use" includes not only radiation safety and protection of radiation sources use, but also transportation, radioactive waste management and decommissioning, etc. On the other hand, the term 'safety culture' is absent from Ukrainian nuclear legislation, namely, in national laws. That is not surprising given the dates these laws were adopted (1995-1997). In the following years a great number of amendments were introduced into the Law of Ukraine "On Nuclear Energy Use" [7]. It is surprising that the lawmakers did not find it necessary to introduce safety culture as part of amendments. Likewise, the term "safety culture" is absent from the Radiation Safety Standard of Ukraine [8]. It is the core document for activities related to nuclear energy use.

Nowadays, safety culture concept is considered a mechanism to identify latent deficiencies of safety and to bring the latter beyond the standards laid down in the legislation and required by the regulators. Therefore, the term 'safety culture' should be introduced in the regulatory framework, but it should be used in quite general expressions, like "the license holder has to follow stated safety culture". The next important step is to develop and implement the guidelines on evaluation, self-evaluation, promotion, strengthening etc. Currently, there are no services aiming to draw up and tailor such guidelines to meet 
L. Aslamova et al., Safety culture as a key issue of radiation medical activities..., Rad. Applic., 2018, 3, 3, 159-164

the needs of particular entities, for example, for activities with the nuclear energy use in medicine.

The term "safety culture" appears in the bylaws, namely in document "On the Approval of General Requirements for the Management System of Activities Related to Nuclear Energy Use" that was approved by the Order No.190 on 19.12 .2011 by the State Nuclear Regulation Inspectorate of Ukraine [9]. This document was drawn up on the basis of national and international experience analysis, the IAEA recommendations and in accordance with the "Action plan to ensure Availability and Accessibility of Information related to Nuclear Energy Use and to Strengthen Nuclear Safety Culture in the Nuclear Industry". In fact, the document represents IAEA safety guide "Application of the management system for facilities and activities. No. GS-G-3.1", but the requirements for safety system in part 3 "Creating and supporting safety culture and protection culture" are not so thoroughly covered as in [10].

The main problem is that the Order [9] contains a restriction: "1.3. These general requirements do not cover healthcare centres that perform diagnostics, treatment and medical procedures using radiation sources". The authors are convinced that the exclusion of diagnostic and treatment procedures for dose formation from streamlining through improved safety culture mechanisms is a poor practice.

Another important legal document for nuclear energy use is "The Requirements for Quality Management System for Diagnostics and Treatment Procedures involving Radiation Sources Use", approved by the Order No.166 on 03.10.2008 by the State Nuclear Regulation Inspectorate of Ukraine [11]. It also needs to be updated. Its main deficiencies and areas for improvement are:

1. Outdated terminology.

2. The term "Code of Quality" is absent. This is a mandatory document for ensuring quality assurance for an enterprise and for obtaining a license for performing certain activities with nuclear energy use.

3. The patient's card needs to be introduced. This is a document registering the procedure appointed, the person who appointed the procedure, the aim of the procedure and the dose the patient will be exposed to.

4. The term "medical physicist" needs to be introduced.

Another very important document on safety culture is "IAEA Safety Standards The management system for nuclear installations. Safety Guide № GS-G-3.5” [12]. The quotation from this document shows the basic principles for safety culture implementation:

"2.10 Senior management should establish and promote a set of principles to be used in decision making and promoting safety conscious behaviour. Examples of such principles used in some organizations are as follows:

(a) Everyone has an impact on safety.

(b) Managers and leaders must demonstrate their commitment to safety.

(c) Trust and open communication permeate the organization. (d) Decision making reflects putting safety first.

(e) Nuclear technology is recognized as having unique safety implications.

(f) A questioning attitude is fostered.

(g) Organizational learning is encouraged.

(h) Training of personnel is encouraged.

(i) A proactive approach to safety is taken.

(j) Safety is constantly under review."

There are a lot of papers, reports etc. on safety in medicine, including safety culture. But the approach is slightly different from the approach for nuclear energy use. For example, «Just Culture» principle is presented by Boysen [13], or the list of the main safety culture elements from [14]. In the last paper a broad range of safety culture properties is identified and organized into seven subcultures and defined as:

1. Leadership: Leaders acknowledge the healthcare environment is a high-risk environment and seek to align vision/mission, staff competency, and fiscal and human resources from the boardroom to the frontline.

2. Teamwork: A spirit of collegiality, collaboration, and cooperation exists among executives, staff, and independent practitioners. Relationships are open, safe, respectful, and flexible.

3. Evidence-based: Patient care practices are based on evidence. Standardization to reduce variation occurs at every opportunity. Processes are designed to achieve high reliability.

4. Communication: An environment exists where an individual staff member, no matter what his or her job description, has the right and the responsibility to speak up on behalf of a patient.

5. Learning: The hospital learns from its mistakes and seeks new opportunities for performance improvement. Learning is valued among all staff, including the medical staff.

6. Just: A culture that recognizes errors as system failures rather than individual failures and, at the same time, does not shrink from holding individuals accountable for their actions.

7. Patient-centered: Patient care is centered around the patient and family. The patient is not only an active participant in his own care, but also acts as a liaison between the hospital and the community.

Thus, when the concept of safety culture is applied to activities with nuclear energy use in medicine, it calls for the enhancement of protection system for patients, personnel an environment. For instance, it should be understood on all levels that nuclear technologies require special attitude to radiation protection and safety. Everyone should remain vigilant when working with ionizing radiation sources.

\section{SAFETY CULTURE IN EDUCATION, TRAINING AND CERTIFICATION OF MEDICAL PHYSICISTS}

Sufficient attention must be paid to safety culture in education, training and continuous professional development of medical physicists. For example, IRPA recommendations on certification schemes for radiation protection experts [4] place high emphasis on checking knowledge, skills and competences of a 
L. Aslamova et al., Safety culture as a key issue of radiation medical activities..., Rad. Applic., 2018, 3, 3, 159-164

candidate. Typical curriculum should cover safety culture of activities with nuclear energy use.

In Ukraine safety culture principles are incorporated into the education and training system for specialists on nuclear energy. That is enshrined in law through the document on the implementation of safety culture principles in Ukraine, the Decree No. 736-p on 03.08.2011 by the Cabinet of Ministers of Ukraine. Its item 6 provides for: “...drawing up a textbook on nuclear safety culture and using it in class in higher education institutions for atomic energy specialists, as an option module". The textbook has been written [15]. Option module on safety culture has been a part of curriculum in Kyiv Polytechnic Institute since 2009 for Bachelor's degree in Atomic Energy. Namely, it is being taught to all students, quite extensively (126 class hours with a final examination) [16]. A more advanced module "The basics of Safety Management" has been taught since 2011. Duration - 162 class hours, it's a part of Specialist's and Master's degree courses.

In medicine with nuclear energy use, medical physicist performs quality assurance and quality control of medical procedure, ensures radiation protection and safety for the patient, personnel and environment. Thus, special training for all mentioned roles and functions is expected, and daily practices should be performed in accordance with the safety culture principles. The Department of Radio Physics, Electronics and Computer Systems of Taras Shevchenko National University of Kyiv has been offering Masters' programmes in Medical Physics, Biomedical Physics, Engineering and Informatics since 2003. Karazin National University of Kharkiv offers Masters' programs in Medical Physics too. Unfortunately, no University course in Ukraine addresses the issues of safety culture well.

It is very important for medical physicists' community to be exposed to international experience and best practices, so as to raise their awareness and improve qualification. Some specialists participate in international events like conferences, trainings, workshops etc, of course, but there is no common practice of sharing the knowledge gained therein in place

The Ukrainian Association of Medical Physicists and Engineers (UAMPE, [17]) jointly with Taras Shevchenko National University of Kyiv propose to hold seminars in the premises of Training and Research Center for Radiation Safety [18]. During the seminars medical physicists will present the results, skills, knowledge obtained during their participation in an interesting event. The report will be obligatory if the UAMPE member participated in an event and was supported by the association. The records of seminar and all support materials will be posted on the UAMPE's website. On the one hand, this allows sharing information; on the other hand, it will be a major contribution to the field report. It is worth noting separately that only a small part of professionals can participate in international events, especially if it is held abroad. Very few medical institutions can send their employees on a study tour or invite international specialists, in part due to lack of funding.
Awareness could also be considerably raised through participation in international interactive projects, for example, Radiation Protection of Patients (RPOP, [19]). It is the IAEA project that brings together a great number of learning materials, guidelines, recommendations and other IAEA documents, information about training events, including on-line seminars. There is a very useful data base called Safety Reporting and Learning System for Radiotherapy (SAFRON, [19]) concerning incidents with nuclear energy use in medicine. Any medical institution can access it. Anyone can obtain and study a range of reports, graphs, statistics etc. Recent times few medical institutions joined to the data bases in the frame of the IAEA Regional project RER9147 "Enhancing Member States' Capabilities for Ensuring Radiation Protection of Individuals Undergoing Medical Exposure". The study will be conducted in the following steps: Phase 1: the participating hospitals answer the questionnaire and submit the completed forms; Phase 2: the departments that participated in the Phase 1 will be invited to provide more detailed data on imaging doses and associated parameters, using a standard data collection form. It is expected that data collected will allow for preparing a scientific paper(s), and if deemed appropriate, a guidance document to help optimize the use of imaging in radiotherapy.

Overseas the specialists, who bear great responsibility for quality control, safety culture, radiation protection etc., must be engaged in continuous professional development, periodically improve their knowledge and, first and foremost, pass certification scheme or obtain a license.

Clearly, there is a need to implement national education system for medical physicists in conjunction with formal certification schemes to recognise and assess their expertise and competences. Such a certification scheme could either be directly under the control of the regulatory body, or operated by a nongovernmental not-for-profit organization. IRPA 2016 Guidance [4] recommends that it can be an associate society, under an approval from the regulatory body, or its activity is regulated by national legislation. Training and Research Center for Radiation Safety of Taras Shevchenko National University of Kyiv [18] has been successfully offering refresher courses and administering the examination on "Radiation Safety for Certain Activities related to Nuclear Energy Use" for more than 14 years. The center has ISO 9001:2008 certificate. Taking into consideration extensive experience, the University of Kiev jointly with nongovernmental not-for-profit organization UAMPE are considering a possibility to introduce certification scheme for radiation protection and medical physics experts. Safety culture is regarded as an integral part of the curriculum, as well as the examination procedure for certification.

\section{CONCLUSION}

Effective introduction of safety culture principles for activities with nuclear energy use in Ukraine calls for the following steps: 
L. Aslamova et al., Safety culture as a key issue of radiation medical activities..., Rad. Applic., 2018, 3, 3, 159-164

1. Improving and adjusting national regulatory and legal framework in order to meet international recommendations. For instance, removing discrepancies in the legal acts, lifting restrictions on safety culture principles implementation in healthcare institutions.

2. Introducing effective education system for training, in-service training and continuous professional development of medical physicists and radiation protection experts. Ensuring the exchange of contemporary experience, practices and information obtained during international meetings, conferences, workshops and other events among these professionals.

3. Creating a certification scheme for radiation protection and medical physics experts with curriculum that would include a module on safety culture.

4. Engaging healthcare institutions and professionals in cooperation as part of international interactive projects like RPOP and sharing their experience globally through international data bases like medical incidents data base SAFRON.

Overall, quite a lot is done in Ukraine to implement safety culture principles into medical activities with nuclear energy use, inter alia thanks to the Eurointegration policy and active ratification of international recommendations, yet much remains to be done.

Acknowledgements: The authors would like to thank Volodymyr Holubiev for comments that significantly improved the manuscript.

\section{REFERENCES}

1. Ю. М. Скалецький та ін., “Вступ” в Культура безпеки на ядерних об’ектах України: наук.методол. посіб, Київ, Україна: ДП «НВЦ «Євроатлантикінформ», 2007. (Yu. M. Skaletskyi, et al., "Introdaction" in Safety culture on nuclear objects of Ukraine: research and methodological textbook Kyiv, Ukraine: DP "NVTs "Euroanalitykinform", 2007.)

2. Radiation Protection and Safety of Radiation Sources: International Basic Safety Standards, General Safety Requirements, No. GSR Part 3, IAEA, Vienna, Austria, 2014.

Retrieved from: https://wwwpub.iaea.org/MTCD/publications/PDF/Pub1578 web57265295.pdf

Retrieved on: Apr. 13, 2018

3. European Commission. (Dec. 5, 2013). Council Directive 2013/59/Euratom laying down basic safety standards for protection against the dangers arising from exposure to ionising radiation.

Retrieved from: https://eur-

lex.europa.eu/LexUriServ/LexUriServ.do?uri=OJ:L:20 14:013:0001:0073:EN:PDF;

Retrieved on: Apr. 13, 2018

4. IRPA Guidance on Certification of a Radiation Protection Expert, IRPA, Paris, France, 2016.

Retrieved from: http://www.irpa.net/docs/IRPA\%20G uidance $\% 200$ \% 20 Certification\%200f\%20a\%20RP\%2 oExpert\%20(2016).pdf;

Retrieved on: Apr. 13, 2018
5. Safety culture, Safety series No.75-INSAG-4, IAEA, Vienna, Austria, 1991. Retrieved from: https://wwwpub.iaea.org/mtcd/publications/pdf/pub882 web.pdf; Retrieved on: Apr. 13, 2018

6. The IAEA Safety Glossary, IAEA, Vienna, Austria, 2008, p. 303.

Retrieved from: http://wwwns.iaea.org/standards/safety-glossary.asp; Retrieved on: Apr. 10, 2018.

7. Верховна рада України. (Лютий о8, 1995). Закон України "Про використання ядерної енергї та радіаційну безпеку". (Supreme Council of Ukraine. (Feb. 8, 1995). Law of Ukraine "Nuclear energy use and radiation safety".)

Retrieved from: http://zakon.rada.gov.ua/laws/show/3 9/95-\%Do\%B2\%D1\%80;

Retrieved on: Mar. 13, 2018

8. Міністерство охорони здоров'я України. (Грудень о1, 1997). Норми радіаційної безпеки Украӥни. Державні гігієнічні нормативи. (Ministry of Health of Ukraine. (Dec. 1, 1997). Radiation safety standard of Ukraine. National hygienic regulations.)

Retrieved from: http://zakon.rada.gov.ua/rada/show/v 0062282-97;

Retrieved on: Mar. 13, 2018

9. Державна інспекція ядерного регулювання України. (Грудень 19, 2011). No 190, Затвердження загальних вимог до системи управління діяльністю у сфері використання ядерної енергї. (State Nuclear Regulation Inspectorate of Ukraine. (Dec. 19, 2011). No 190, Adoption of general requirements to management system of activities related to nuclear energy use.)

Retrieved from: http://zakon2.rada.gov.ua/laws/show/ zo017-12;

Retrieved on: Mar. 20, 2018

10. Application of the management system for facilities and activities, Safety guide No. GS-G-3.1, IAEA, Vienna, Austria, 2006.

Retrieved from: https://wwwpub.iaea.org/MTCD/publications/PDF/Pub1253 web. pdf;

Retrieved on: Mar. 21, 2018

11. Державна інспекція ядерного регулювання України. (Жовтень 03, 2008). Вимоги до системи управління якістю проведення діагностичних та терапевтичних процедур 3 використанням джерел іонізуючого випромінювання. (State Nuclear Regulation Inspectorate of Ukraine. (Oct. 3, 2008). No 166 Requirements to quality management system for performing of diagnostics and treatment procedures with radiation sources use.)

Retrieved from: http://zakon2.rada.gov.ua/laws/show/ z1054-08;

Retrieved on: Mar. 1, 2018

12. The management system for nuclear installations, Safety Guide No.GS-G-3.5, IAEA, Vienna, Austria, 2009.

Retrieved from: http://www-

pub.iaea.org/MTCD/publications/PDF/Pub1392 web. pdf;

Retrieved on: Mar. 1, 2018

13. P. G. Boysen II, "Just Culture: A Foundation for Balanced Accountability and Patient Safety," Ochsner J., vol. 13, no. 3, pp. 400 - 406, 2013.

PMid: 24052772

PMCid: PMC 3776518

14. C. E. Sammer, K. Lykens, K. P. Singh, D. A. Mains, N. A. Lackan, "What is Patient Safety Culture? A Review of the Literature," J. Nurs. Scholarsh., vol. 42, no. 2, pp. $156-165$, Jun. 2010.

DOI: 10.1111/j.1547-5069.2009.01330.x 
L. Aslamova et al., Safety culture as a key issue of radiation medical activities..., Rad. Applic., 2018, 3, 3, 159-164

PMid: 20618600

15. В.В. Бєгун та ін., "Визначення і харакреристика культури безпеки,” в Культура безпеки в ядерній енергетиці: Підручник, Київ, Україна, 2012. (V.V. Begun et al., "Definition and description of Safety Culture," in Safety culture in nuclear power engineering: textbook, Kyiv, Ukraine, 2012.)

Retrieved from:

http://www.immsp.kiev.ua/postgraduate/Biblioteka tr udy/KulturaBezpekyBegun2012.pdf

Retrieved on: Feb. 5, 2018

16. Ю. М. Скалецький, Д. С. Бірюков, О. О. Мартюшева, Л. Д. Яценко, Проблеми впровадження культури безпеки в Украӥні: аналіт. доп., НІСД, Київ, Україна, 2012. (Yu. M. Skaletskyi, D. S. Birjukov, O. O. Martjusheva, L. D. Yatsenko, Problems of implementation of safety culture in Ukraine: Analytical report, NISD, Kyiv, Ukraine, 2012)
Retrieved from: http://www.niss.gov.ua

Retrieved on: Feb. 5, 2018

17. Всеукрайнсъке об'єднання медичних фізиків та інженерів, Київ, Україна, 2018. (Ukrainian Association of Medical Physicists and Engineers, Kyiv, Ukraine, 2018.)

Retrieved from: http://vomfi.univ.kiev.ua/

Retrieved on: May 5, 2018

18. Навчально-науковий центр радіаційної безпеки, Київ, Україна, 2018. (Training and Scientific Center of Radiation Safety, Kyiv, Ukraine, 2018.)

Retrieved from: http://rb.univ.kiev.ua/

Retrieved on: May 5, 2018

19. Radiation Protection of Patients, IAEA, Vienna, Austria, 2018.

Retrieved from: https://www.iaea.org/resources/rpop Retrieved on: May 5, 2018 